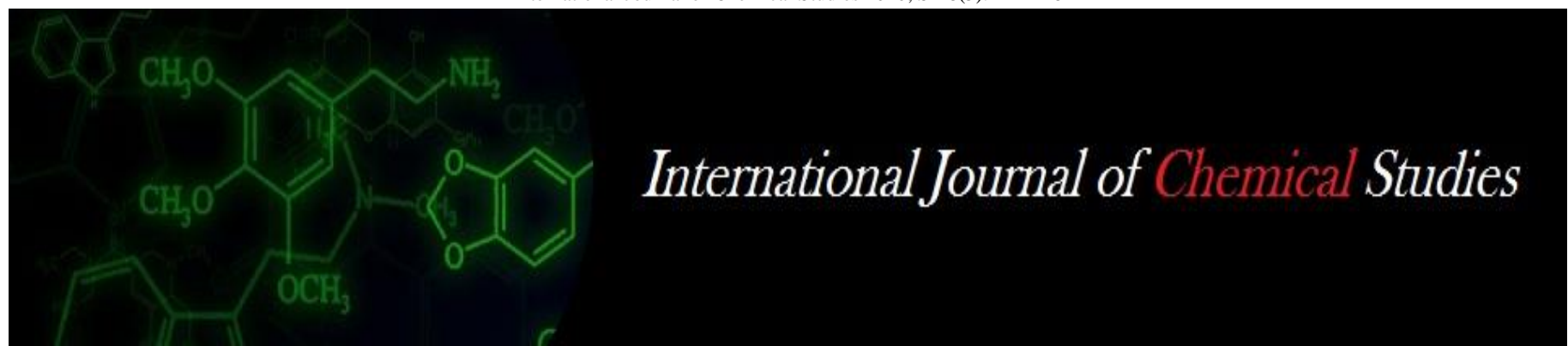

P-ISSN: 2349-8528

E-ISSN: 2321-4902

www.chemijournal.com

IJCS 2020; SP-8(5): 244-248

(C) 2020 IJCS

Received: 30-06-2020

Accepted: 06-08-2020

Shiv Prakash Sonkar

Scientist, Agricultural

Extension, Krishi Vigyan

Kendra, Hamirpur, Uttar

Pradesh, India

Atik Ahamad

SMS, Soil Science, Krishi Vigyan

Kendra, Jhansi, Uttar Pradesh,

India

Shalini

SMS, Agronomy, Krishi Vigyan

Kendra, Hamirpur, Uttar

Pradesh, India

\section{Socioeconomic factors affecting vegetable production in Western Uttar Pradesh}

\author{
Shiv Prakash Sonkar, Atik Ahamad and Shalini
}

DOI: https://doi.org/10.22271/chemi.2020.v8.i5e.10617

\begin{abstract}
The present paper attempts to examine the personal and socio-economic profile of vegetable farmers of Meerut and Sharanapur district of Western Uttar Pradesh. The study was conducted in sixteen villages located at Kharkhauda, Daurala and Nangal, Deoband block of Meerut and Sharanapur districts. Data for the study was collected from a sample of 160 vegetable farmers. The findings of the study reveal that, the $25.00 \%$ of the vegetable farmers had intermitted education. Among the sample about 54.37 percent of farmers were medium. 84.37 percent farmers were pacca house, $25 \%$ vegetable cultivation as main occupation, The annual income of vegetable farmers revealed that About 51.25 percent were found in the medium income category ranging from 50,000 to 1,00,000, electric Tube well of the farmers were $53.12 \%$. The study revealed that vegetable farmers had medium level of socio-economic status.
\end{abstract}

Keywords: Vegetable, income category, cultivation

\section{Introduction}

Vegetables play a pivotal role in Indian agriculture by providing food, nutritional and economic security to the people of India with higher returns per unit area to the producers. In addition, vegetable crops have higher productivity and shorter maturity cycle, which leads to higher returns per unit area and time. Worldwide, India holds the second position by contributing 15.70 and $14.50 \%$ to global vegetable area and production, respectively. In our country, vegetable production is threatened by fragmentation of land, climate change, decreasing natural resources and uneven growth across the country. Uttar Pradesh state of India shares $26 \%$ in total horticulture production of the country. It ranks third in fruits, second in vegetable and first position in potato production among all states. This state is the second largest producer of vegetables in the country after West Bengal. The vegetable cultivation has an increasingly important commercial role, especially for low income households (Gockowski, J. and Ndoumbe M. 2004) ${ }^{[1]}$. It has great potentiality and scope for improving socioeconomic condition of small and marginal farmers since it provides higher yield and high economic return in short time as compared to food grains. It has more income per unit area and employment generation in short span of time and thereby have attracted the farmers of the state. These crops have proved to be the boon to the small and marginal farmers of the state who accounts for more than $90 \%$ holding of the State. It was, therefore, required to study the profile of vegetable growers to get some knowledge about socio economic profile of vegetable growers. Forward caste farmers who had land in plenty could afford vegetable cultivation, whereas this was not the case for backward, scheduled caste and scheduled tribe farmers. (Singh 2000) ${ }^{[2]}$. More than half $(59.17 \%)$ of the respondents had level of social participation (Venkatesan 2000) ${ }^{[8]}, 42.3$ percent of them were found to be small onion growers $(<2$ acres), 32.69 percent were medium growers (2-4 acres), 15.38 percent were big growers (4- 6 acres) and finally only 9.61 per cent of the respondents were large growers (Kumar 2001) [6], majority of the respondents $(35.83 \%)$ had high school education, followed by middle school (25.00\%), primary (16.67\%) and collegiate level (15.00\%) (Dhamodaran and Vasantha 2001) [7]. Socio- personal attributes of vegetable growers belonged to all the age groups, had medium to high level of education belonged to OBC caste category, joint and small families, small landholders live in their own pakka houses, have medium level of material possession and form power, acquired high level of vegetable growing experience with regards to psychological attributes, it is suggested that vegetables growers had good,
Corresponding Author: Shiv Prakash Sonkar Scientist, Agricultural Extension, Krishi Vigyan Kendra, Hamirpur, Uttar Pradesh, India 
marketing orientation, medium level of aspiration, and had their favorable attitude toward vegetable cultivation (Khare et al. 2001).

\section{Research Methodology}

The study was conducted in Meerut and Saharanpur districts of Western Uttar Pradesh. Because in this area only the districts in vicinity of metropolitan market could supply fresh vegetable. As the good transportation facility is pre-requisite for better transportation and marketing. As the investigator is from Sardar Vallabhbhai Patel University of Agriculture and Technology, Meerut, keeping the convenience for the study in mind, the above districts were purposively selected for this study. In order to have a better understanding to the findings of any research study, it is necessary to have a complete understanding of the physical and socio-economic conditions of the area in which the investigation of such a study has been carried out. This provides sound basis for testing the validity of the results of similar studies

Location of District Meerut: The district Meerut is situated at Latitudes $29.18^{\circ}$ North and Longitudes $78.7^{\circ}$ east. Its total geographical area is 2590 square K.M. It has 3 Tehsils, namely Meerut, Mawana, Saradhana, and 12 community development blocks, namely: Saroorpur Khurd, Machhara, Saradhana, Rohata, Daurala, Jani Khurd, Mawana Kalan, Meerut, Hastinapur, Rajpura, Parikshitgarh, Kharkhauda.

Location of District Saharanpur: The district Saharanpur is situated at Latitudes $29.96^{\circ}$ North and Longitudes $77.55^{\circ}$ east.
Its total geographical area is 3689 square K.M. It has 5 Tehsils, namely Saharanpur, Nakur, Behat, Deoband, Rampur Maniharan, and 11 community development blocks, namely: Baniakhera kshetra, Deoband, Gangoh, Mujaffarabad, Nagol, Nakur, Nanauta, Punwarka, Rampur, Sadhaulikadeem, Sarsawan,

List of Blocks and Villages selected for the study

\begin{tabular}{|c|c|c|c|c|c|}
\hline \multicolumn{6}{|c|}{ Locale of study } \\
\hline Unit & \multicolumn{4}{|c|}{ Particulars } & Design \\
\hline Zone & \multicolumn{4}{|c|}{ Western Uttar Pradesh } & purposively \\
\hline District (2) & Mee & & \multicolumn{2}{|c|}{ Saharanpur } & purposively \\
\hline Block (4) & Kharkhauda & Daurala & Nangal & Deoband & purposively \\
\hline \multirow[b]{2}{*}{ Village (16) } & Kharkhauda & Dhanju & Chandena & Sakhankala & \multirow[b]{2}{*}{ Randomly } \\
\hline & $\begin{array}{l}\text { Khaspur } \\
\text { Bijoli } \\
\text { Nalpur }\end{array}$ & $\begin{array}{c}\text { Mithepur } \\
\text { Lawar } \\
\text { Dedava }\end{array}$ & $\begin{array}{c}\text { Piror } \\
\text { Suhagani } \\
\text { Ambauli }\end{array}$ & $\begin{array}{c}\text { Deoband } \\
\text { Talheri } \\
\text { Manki }\end{array}$ & \\
\hline Respondents & \multicolumn{4}{|c|}{160} & Randomly \\
\hline
\end{tabular}

Selection of Respondents: In order to have an accurate and valid generalization, it requires drawing adequate size of sample of respondents from the group of 16 villages in the selected area. Keeping this in mind 10 vegetable growers were selected randomly from the each selected village. Thus the total sample size of 160 commercial vegetable growers.

Selection of crops: For this study two vegetable crops i.e. Potato and cauliflower were selected purposely, because in terms of area, these crops were dominating over other vegetable crops in Meerut and Saharanpur districts.

Variables and Their Measurement

\begin{tabular}{|c|c|c|}
\hline S. No. & Variables & Empirical measurements \\
\hline & Independent variable & \\
\hline 1. & Age & Socio-economic status (rural) developed Singh et al. $(2005){ }^{[3]}$ with suitable modification. \\
\hline 2. & Education & Socio-economic status (rural) developed Singh et al. $(2005)^{[3]}$ with suitable modification. \\
\hline 3. & Caste & Socio-economic status (rural) developed Singh et al. $(2005)^{[3]}$ with suitable modification. \\
\hline 4. & Family type & Socio-economic status (rural) developed Singh et al. $(2005){ }^{[3]}$ with suitable modification. \\
\hline 5. & Family size & Socio-economic status (rural) developed Singh et al. $(2005){ }^{[3]}$ with suitable modification. \\
\hline 6. & Housing pattern & Socio-economic status (rural) developed Singh et al. $(2005)^{[3]}$ with suitable modification. \\
\hline 7. & Occupation & Socio-economic status (rural) developed Singh et al. (2005) ${ }^{[3]}$ with suitable modification. \\
\hline 8. & Annual family income & Socio-economic status (rural) developed Singh et al. (2005) ${ }^{[3]}$ with suitable modification. \\
\hline 9. & Land size & Schedule developed \\
\hline 10. & Source of Land & Schedule developed \\
\hline 11. & Sources of irrigation & Schedule developed \\
\hline 12. & Facilities available & Schedule developed \\
\hline 13. & Social participation & Socio-economic status (rural) developed Singh et al. $(2005){ }^{[3]}$ with suitable modification. \\
\hline
\end{tabular}

Data collection procedure: Interview schedule was developed for data collection. The data was collected through personal interview with the help of pre-structured and pretested interview schedule then modification of interview schedule to maintain reliability and validity of data.

Methods of statistical analysis: After data collection, the data was classified, tabulated and analyzed in the light of the objectives. Appropriate Statistical techniques were applied i.e.

Measurement of knowledge: It was operationalized as the extent to which an individual has knowledge of recommended commercial vegetable package of practices and was measured with the help of structured schedule. Responses were recorded on 3 point continuous full knowledge, partial knowledge and no knowledge and were given 3, 2, and 1 score, respectively.
On the basis of obtained score the mean were calculated and rank were assigned.

No. of respondents $\mathrm{x}$ assigned score on the category belonged to assigned category

Mean score $=\frac{\text { No. of respondents }}{\text { Non }}$

Measurement of adoption of commercial vegetable growing practices: It was operationalized as the degree to which respondents have adopted the recommended vegetable growing practices and was measured with the help of structured schedule. The responses were recorded on 3 point continuum as fully, partial and no adoption and were given 3 , 2, 1 scores, respectively. On the basis of obtained score the mean were calculated and assigned the rank order. 
Measurement of constraints: Various type of constraints related to vegetable production was measured of with the help of three point rating scale.

Percentage This was used for making sample comparison. To calculate the percentage, the frequency of a particular cell was multiplied by 100 and divided by the total number of respondents in that particular category.

Frequency of particular cell x 100

Percentage $=\frac{\text { No. of respondents }}{\text { Non }}$

Rank order /Frequency distribution: The various ranks were given on the basis of highest to the lowest frequency. It was used to find out the number of respondents in the particular cell.

Pearson's product moment correlation: This measure was used to find out the relationship between the different combinations of production advancement viz., knowledge, adoption of farmers. Coefficient of correlation was also found out between the knowledge and adoption variables. The formula used for calculating correlation coefficient value was as below:

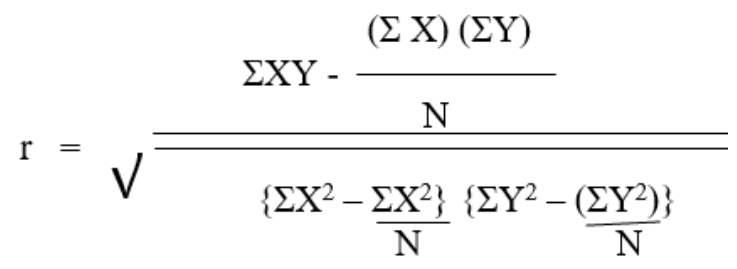

Where as:

$\mathrm{X}$ and $\mathrm{Y}=$ Variable being correlated

$\mathrm{r}=$ Correlation coefficient between $\mathrm{X}$ and $\mathrm{Y}$

$\Sigma \mathrm{X} \mathrm{Y}=$ Sum of products of $\mathrm{X}$ and $\mathrm{Y}$

$\Sigma \mathrm{X}=$ Summation of overall cell entries of first variable

$\Sigma \mathrm{Y}=$ Summation of overall cell entries of second variable

$\Sigma \mathrm{X}^{2}=$ Sum of squares all required value of each cell of first variable

$\Sigma Y^{2}=$ Sum of squares all required value of each cell of second variable

Frequency, percentage, average, means score, rank order and coefficient of correlation etc. The pre-tested interview schedule was used for collection of data and the data was analysed by using appropriate statistical methods such as percentage $(\%)$, mean and standard deviation.

\section{Results and Discussion}

Tables \& figure 1 presented that the majority of the respondents 48.75 percent belonged to middle age group ranging 30 to 45 years. Followed by 26.88 percent respondents belonged to young age group ranging up to 30 years and remaining 24.37 percent respondents belonged to old age group, above 45 years. Thus, it can be concluded that the majority of the respondents (48.75 percent) belonged to Middle age group ranging 30 to 45 years. Similar type of finding were also reported by (Prakash Vinod, 2007) ${ }^{[5]}$.

Table 1: Distribution of the respondents on the basis of their Age group

\begin{tabular}{|c|c|c|c|}
\hline S. No. & Particulars & Frequency & Percentage \\
\hline 1. & Young age (up to 30 years) & 43 & 26.88 \\
\hline 2. & Middle age (30-45 years) & 78 & 48.75 \\
\hline 3. & Old age (above 45 years) & 39 & 24.37 \\
\hline \multicolumn{2}{|c|}{ Total } & $\mathbf{1 6 0}$ & $\mathbf{1 0 0}$ \\
\hline
\end{tabular}

\section{Distribution of the respondents on the basis of their Age group}

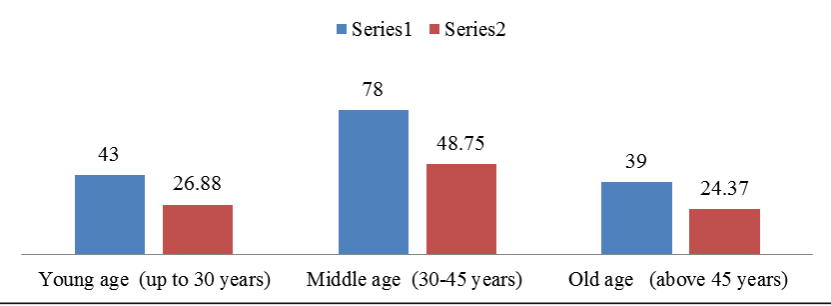

Fig 2: Distribution of the respondents on the basis of their Age group

Table 2 presented that maximum 57.50 percent respondents belonged to other backward classes fallowed by 34.38 percent respondents belonged to general category and only 8.12 percent respondents belonged to schedule caste/schedule tribe category. Thus it can be concluded that maximum 57.50 percent respondents belonged to other backward class.

Table 2: Distribution of the respondents on the basis of their Caste category

\begin{tabular}{|c|c|c|c|}
\hline S. No. & Particulars & Frequency & Percentage \\
\hline 1. & General category & 55 & 34.38 \\
\hline 2. & Other backward classes & 92 & 57.50 \\
\hline 3. & Schedule caste / Scheduled Tribe & 13 & 8.12 \\
\hline \multicolumn{2}{|r|}{ Total } & $\mathbf{1 6 0}$ & $\mathbf{1 0 0}$ \\
\hline
\end{tabular}

Table.3 presented that the maximum 25.00 percent commercial vegetable growers were having $12^{\text {th }}$ class educational qualification followed by $18.75,13.75,13.75$, 12.50 and 9.37 per cent commercial vegetable growers were having $10^{\text {th }}, 8^{\text {th }}$, and 5 th, post graduate and graduation level of educational qualification, respectively. Only 6.88 percent commercial vegetable growers were illiterate. Thus, it can be concluded that the majority of the commercial vegetable growers were literate.

Table 3: Distribution of the respondents on the basis of their Educational status

\begin{tabular}{|c|c|c|c|}
\hline S. No. & Particulars & Frequency & Percentage \\
\hline 1. & Illiterate & 11 & 6.88 \\
\hline 2. & $5^{\text {th }}$ Pass & 22 & 13.75 \\
\hline 3. & $8^{\text {th }}$ Pass & 22 & 13.75 \\
\hline 4. & $10^{\text {th }}$ Pass & 30 & 18.75 \\
\hline 5. & $12^{\text {th }}$ Pass & 40 & 25.00 \\
\hline 6. & Graduation & 15 & 9.37 \\
\hline 7. & Post-graduation \& above & 20 & 12.50 \\
\hline \multicolumn{2}{|c|}{ Total } & $\mathbf{1 6 0}$ & $\mathbf{1 0 0}$ \\
\hline
\end{tabular}

Table 4 presented that the majority 75.00 percent of the respondents belonged to nuclear family system and remaining 25.00 percent respondents belonged to joint family system. 
Thus, it can be said that the majority of (75.00 percent) respondents belonged to nuclear family system and interested for commercial vegetable growing.

Table 4: Distribution of the respondents on the basis of their family type

\begin{tabular}{|c|c|c|c|}
\hline S. No. & Particulars & Frequency & Percentage \\
\hline 1. & Joint family & 40 & 25.00 \\
\hline 2. & Nuclear family & 120 & 75.00 \\
\hline \multicolumn{2}{|c|}{ Total } & $\mathbf{1 6 0}$ & $\mathbf{1 0 0}$ \\
\hline
\end{tabular}

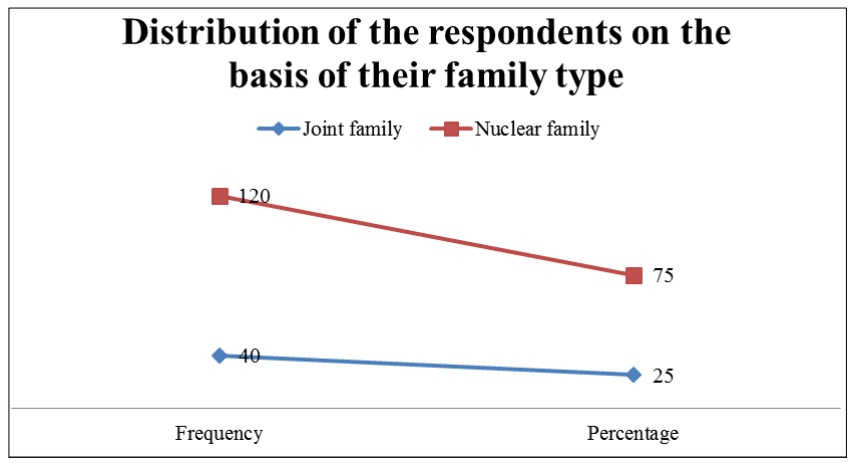

Fig 2: Distribution of the respondents on the basis of their family type

Table 5 presented that the maximum 54.37 percent respondents of commercial vegetable growers were having medium size (4 to 6 members) of family followed by 23.13 , 12.50 and 10.00 percent commercial vegetable growers were having small, large and very large size of family, respectively. Thus, it can be concluded that the maximum 54.37 percent commercial vegetable growers were having either medium size (4 to 6 members) of the family. Similar type of findings were also reported by (Rokonuzzaman 2013) ${ }^{[4]}$.

Table 5: Distribution of the respondents on the basis of their size of family

\begin{tabular}{|c|c|c|c|}
\hline S. No. & Particulars & Frequency & Percentage \\
\hline 1. & Small (up to 3) & 37 & 23.13 \\
\hline 2. & Medium (4 to 6$)$ & 87 & 54.37 \\
\hline 3. & Large (6 to 10$)$ & 20 & 12.50 \\
\hline 4. & Very large (more than 10$)$ & 16 & 10.00 \\
\hline \multicolumn{2}{|r|}{ Total } & 160 & 100 \\
\hline
\end{tabular}

Table.6 presented that the maximum 8.4.37 percent commercial Vegetable growers were having pucca houses followed by 12.50 percent were possessing mixed house and remaining 3.13 percent commercial vegetable growers were having Katcha house. Thus, it can be concluded that the maximum 84.37 percent commercial vegetable growers were having pucca houses.

Table 6: Distribution of the respondents on the basis of their Housing pattern

\begin{tabular}{|c|c|c|c|}
\hline S. No. & Particulars & Frequency & Percentage \\
\hline 1. & Katcha Houses & 5 & 3.13 \\
\hline 2. & Mixed (Katcha+ Pucca) Houses & 20 & 12.50 \\
\hline 3. & Pucca Houses & 135 & 84.37 \\
\hline \multicolumn{2}{|r|}{ Total } & 160 & 100 \\
\hline
\end{tabular}

Table 7 presented that the majority of the respondents $(75.00$ percent) were doing farming of commercial vegetable as a subsidiary occupation. Under this category 52.50 percent respondents were doing Agriculture followed by 15.62 and
6.88 percent Vegetable growers were doing Agriculture + Business and Agriculture+ Business+ Service, respectively. Only 25.00 percent respondents were gowing commercial vegetable as a main occupation. Thus, it is clear from the above Table 7 that only 25 percent respondents were dependent upon commercial vegetable cultivation and 75.00 percent respondents were growing commercial vegetable as a subsidiary occupation. Table. 8 represented that the maximum 51.25 percent commercial vegetable growers were having Rs. 50,000 to $1,00,000$ annual income followed by $25.00,17.50$ and 6.25 percent commercial vegetable growers were having more than 1,00,000,20,000 to 50,000 and up to 20,000 annual income, respectively. Thus, it is clear from the above.

Table 7: Distribution of the respondents on the basis of their Occupation

\begin{tabular}{|c|c|c|c|}
\hline S. No. & Particulars & Frequency & Percentage \\
\hline $\mathbf{a}$ & $\begin{array}{l}\text { Vegetable cultivation as Main } \\
\text { occupation }\end{array}$ & 40 & 25.00 \\
\hline b & \multicolumn{3}{|c|}{ Vegetable cultivation as subsidiary $(75 \%)$ occupation } \\
\hline 1. & Agriculture & 84 & 52.50 \\
\hline 2. & Agriculture + Business & 25 & 15.62 \\
\hline 3. & Agriculture + Business + Service & 11 & 06.88 \\
\hline & Total & 160 & 100 \\
\hline
\end{tabular}

Table 8 that the maximum 51.25 percent commercial vegetable growers were having annual income Rs. 50,000 to $1,00,000$.

Table 8: Distribution of the respondents on the basis of their Annual Income

\begin{tabular}{|c|c|c|c|}
\hline S. No. & Particulars & Frequency & Percentage \\
\hline 1. & More than Rs. $1,00,000$ & 40 & 25.00 \\
\hline 2. & Rs. $50,000-1,00,000$ & 82 & 51.25 \\
\hline 3. & Rs. $20,000-50,000$ & 28 & 17.50 \\
\hline 4. & Rs. Up to 20,000 & 10 & 06.25 \\
\hline \multicolumn{2}{|c|}{ Total } & $\mathbf{1 6 0}$ & $\mathbf{1 0 0}$ \\
\hline
\end{tabular}

Table 9 revealed that the maximum 27.50 percent commercial vegetable grower were having 5 to 10 ha of land holdings followed by $25.00,22.50,18.75$ and 6.25 percent respondents of the commercial vegetable growers were having 2 to 5 ha, less than 1 ha, 1-2 ha and more than 10 ha, land respectively. Thus, it is clear from the above the maximum 27.50 percent commercial vegetable growers were having 4 to 10 ha of land holding size.

Table 9: Distribution of the respondents on the basis of their size of holdings

\begin{tabular}{|c|c|c|c|}
\hline S. No. & Particulars & Frequency & Percentage \\
\hline 1. & Marginal (Less than 1 ha) & 36 & 22.50 \\
\hline 2. & Small (1-2 ha) & 30 & 18.75 \\
\hline 3. & Semi Midium (2-4 ha) & 40 & 25.00 \\
\hline 4. & Midium (4-10 ha) & 44 & 27.50 \\
\hline 5. & Large (More than 10 ha) & 10 & 6.25 \\
\hline \multicolumn{2}{|c|}{ Total } & $\mathbf{1 6 0}$ & $\mathbf{1 0 0}$ \\
\hline
\end{tabular}

Table 10 shows that the maximum 53.12 percent commercial vegetable growers were using Electric Tube well as a source of irrigation followed by $30.63,13.12,1.88$, and 1.25 percent commercial vegetable growers were using Tube well (diesel Engine), canal, sprinkler irrigation and drip irrigation, respectively. Thus, it is clear from the above the maximum 53.12 percent commercial vegetable growers were used 
electric tube well as a main source of irrigation in commercial vegetable in the study area.

Table 10: Distribution of the respondents on the basis of their sources of irrigation.

\begin{tabular}{|c|c|c|c|}
\hline S. No. & Particulars & Frequency & Percentage \\
\hline 1. & Tube Well (Diesel Engine) & 49 & 30.63 \\
\hline 2. & Electric Tube well & 85 & 53.12 \\
\hline 3. & Canal & 21 & 13.12 \\
\hline 4. & Sprinkler irrigation & 03 & 1.88 \\
\hline 5. & Drip irrigation & 02 & 1.25 \\
\hline \multicolumn{2}{|c}{ Total } & $\mathbf{1 6 0}$ & $\mathbf{1 0 0}$ \\
\hline
\end{tabular}

Table 11 presented that 50.00 percent respondents were having most common facilities in household assets such as T.V., Radio. Mobile, Fan, Bathroom, Gas connection etc. and belonged to the medium category followed by 28.12 percent respondents were having at least low level of common household facilities and belonged to low level category and only 21.88 percent respondents were having the almost all type of household facility in their houses such as A.C., cooler, freeze, modern furniture, washing machine, computer etc. and belonged to high level category material possession. It is clear from table 11 that the majority ( 58.13 percent) of commercial vegetable growers have Cycle, 55.63 percent have Bullet/Motorcycle, 45.00 percent Jhotabuggi, 21.88 percent car and 20.63 percent have Tractor trolley, respectively. It is concluded that the maximum percentage of commercial vegetable growers have Cycle, Bullet/Motorcycle and Jhotabuggi.

Table 11: Distribution of Commercial Vegetable growers according to their material possession: (Home appliances)

\begin{tabular}{|c|c|c|c|}
\hline \multirow{2}{*}{ S. No. } & \multirow{2}{*}{ Particulars } & \multicolumn{2}{|c|}{ N=160 } \\
\cline { 3 - 4 } & & Frequency & Percentage \\
\hline 1. & Low & 45 & 28.12 \\
\hline 2. & Medium & 80 & 50.00 \\
\hline 3. & High & 35 & 21.88 \\
\hline \multicolumn{2}{|c|}{ Total } & $\mathbf{1 6 0}$ & $\mathbf{1 0 0}$ \\
\hline
\end{tabular}

Table 12: Distribution of Commercial Vegetable growers according to their material possession: (Transportation facility)

\begin{tabular}{|c|c|c|c|}
\hline \multirow{2}{*}{ S. No. } & \multirow{2}{*}{ Particulars } & \multicolumn{2}{|c|}{ N=160 } \\
\cline { 3 - 4 } & & Frequency & Percentage \\
\hline 1. & Cycle & 93 & 58.13 \\
\hline 2. & Jhotabuggi & 72 & 45.00 \\
\hline 3. & Two wheeler & 89 & 55.63 \\
\hline 4. & Four wheeler & 35 & 21.88 \\
\hline 5. & Tractor trolley & 33 & 20.63 \\
\hline
\end{tabular}

Table 12 revealed that 53.12 percent respondents were having most common farm facilities such as tractor, trolley, harrow cultivator, thrasher, leveller and belonged to the medium category level of farm assets followed by 27.50 percent respondents were not having the ownership of heavy farm assets. They use implements on rental basis and belonged to low category level of farm assets ownership and only 19.38 percent respondents were having all types of agricultural implements such as laser leveller, tractor, cultivator, thrasher, harrow plough, seed drill, potato sowing and digger machine and etc. they also reported that such owned farm machinery were also given on rent to other vegetable growers.

The data presented in Table 13 shows that the majority of respondents 86.25 percent were not participating in any formal/informal organizations, followed by 10.63 percent respondents were participating in one formal organization and remaining 3.12 percent respondents were participating in more than one formal / non formal organization.

Table 13: Distribution of Commercial Vegetable growers according to their material possession: (Transportation facility)

\begin{tabular}{|c|c|c|c|}
\hline \multirow{2}{*}{ S. No. } & \multirow{2}{*}{ Particulars } & \multicolumn{2}{|c|}{ N=160 } \\
\cline { 3 - 4 } & & Frequency & Percentage \\
\hline 1. & Low & 44 & 27.50 \\
\hline 2. & Medium & 85 & 53.12 \\
\hline 3. & High & 31 & 19.38 \\
\hline \multicolumn{2}{|c|}{ Total } & $\mathbf{1 6 0}$ & $\mathbf{1 0 0}$ \\
\hline
\end{tabular}

\section{Conclusion}

Approx 53.12 percent respondents were having most common farm facilities such as tractor, trolley, harrow cultivator, thrasher, leveller belonged to the medium category of farm assets followed by 27.50 percent respondents were not having the ownership of heavy farm assets. They were using implements on rental basis and belonged to low category of farm assets ownership only 19.38 percent respondents were having all types of agricultural implements such as laser leveler, tractor, cultivator, thrasher, harrow plough, seed drill, potato sowing and digger machine etc. They also reported that such owned farm machinery, also give on rent to other vegetable growers.

The socioeconomic characteristics of farmers are important for better policy formal organization options. On the basis of the findings it is suggested that socio-economic status of the farmers can be improved by imparting technical knowledge/ training to vegetable farmers, increasing their education level and increasing their social participation.

\section{References}

1. Gockowski J, Ndoumbe M. The Adoption of Intensive Monocrop Horticulture in Southern Cameroon. Agricultural Economics. 2004; 30:195-202.

2. Singh BK. Commercialization of vegetable cultivationAn institution intervention Unpublished Ph.D. (Ag.) thesis, Division of Agricultural Extension IARI, New Delhi, 2000.

3. Singh R, Shyam R, Kumar S. Manual for Socio Economic Status Scale, National Psychological Corporation 4/230, Kacheri Ghat, Agra (India), 2005.

4. Rokonuzzaman M. Training needs of tribal people in carrying out income generating activities. Indian Research Journal of Extension Education. 2013; 13(1):77-84.

5. Prakash V. Adoption extent of potato respondents about potato production technology. International Journal of Agricultural Sciences. 2007; 3(1):223-227.

6. Kumar V. A study of technological gaps in onion production and post-harvest constraints of onion growers of Najafgarh block of Delhi. Unpublished M. Sc. (Agri.) thesis, Department of Agricultural Extension, Chaudhary Charan Sinngh University, Merrut, (U.P.), 2001.

7. Dhamodra T, Vasantha KJ. Relationship between selected characteristics of registered sugarcane growers and their extent of adoption of improved sugarcane cultivation practices. Journal of Extension Education, 2001; 12(2):3138-3143.

8. Venkatesan S. Awareness, knowledge and adoption level of recommended tomato cultivation Practices in Tamil Nadu. Unpub. M. Sc. (Ag.) thesis, Department of Agricultural Extension and Sociology, TN AU, Coimbatore, 2000. 